\title{
Degree of naturalization of non-native plants on dumps
}

\author{
Oleg Kupiyanov, ${ }^{1,2}$ Andrey Kupiyanov ${ }^{1, *}$ and Baurjan Turalin ${ }^{3}$ \\ ${ }^{1}$ The Federal Research Center of Coal and Coal Chemistry of Siberian Branch of the Russian \\ Academy of Sciences \\ ${ }^{2}$ Federal Research Center for Information and Computational Technologies of Siberian Branch of the \\ Russian Academy of Sciences \\ ${ }^{3}$ Aktobe Regional State University named after K. Zhubanov
}

\begin{abstract}
The presence of non-native plants on dumps in Kuzbass was studied. 26 plants included in the Black Book of Flora of Siberia were identified: Acer negundo, Amoria hybrida, Atriplex sagittata, Conium maculatum, Conyza canadensis, Echinochloa crusgalli, Echinocystis lobata, Echium vulgare, Elaeagnus angustifolia, Epilobium adenocaulon, Hordeum jubatum, Impatiens glandulifera, Lactuca serriola, Lepidium densiflorum, Lepidotheca suaveolens, Lupinus polyphyllus, Malus baccata, Medicago sativa, Melilotus officinalis, Oenothera villosa, Pastinaca sativa, Plantago lanceolata, Senecio vulgaris, Solidago canadensis, Tripleurospermum inodorum, Ulmus pumila. Non-native plants occur at all stages of syngenesis and are of great importance in the formation of the vegetation on dumps. Colonophytes-agriophytes and epecophytes have a high degree of naturalization: Amoria hybrida (mountain taiga subbelt), Epilobium adenocaulon, Medicago sativa, Melilotus officinalis, Oenothera villosa (mountain taiga subbelt), Pastinaca sativa, Tripleurospermum inodorum, Ulmus pumila (southern forest-steppe subzone).
\end{abstract}

\section{Introduction}

Rock dumps form technogenic landscape without soil and vegetation cover. Dump colonization by the higher plants obeys certain laws of syngenesis. Three stages of syngenesis were identified in the dumps of Kuzbass: the pioneer stage, the group-thicket stage, and the stage of primary phytocenosis [1]. The initial introduction of propagules to the dumps is regulated exclusively by the peculiarities of the floral composition of the adjacent territories and human activity [2]. The the dumps flora of Kuzbass includes 557 species of vascular plants from 79 families [3].

Climate change and globalization in all spheres of human activity has changed the possibilities of plant survival in new conditions [4]. This is facilitated by the anthropogenic transformation of flora, as a result of which there is a weakening of competitive relations in natural ecosystems and "black holes" are formed through which alien species enter technogenically transformed landscapes.

\footnotetext{
${ }^{*}$ Corresponding author: kupr-42@yandex.ru
} 
habitats and do not go beyond them, third ones after a while naturalized and transform natural communities. 58 invasive species were identified in the flora of Siberia, including 49 in the territory of Kuzbass [5]. The purpose of this report is to assess the degree of naturalization of invasive species on dumps.

\section{Materials and Methods}

The research was carried out on 14 dumps of open-pit development of a coal deposit and coal mines in the forest-steppe zone, in three botanical and geographical subzones: the southern forest-steppe (open-pit development of a coal deposit Bachatsky, Berezovsky, Vakhrushevsky, Mokhovsky, Sartakinsky, Taldinsky, Pionerskaya mine), the northern forest-steppe (Krasnogorsky, Listvyansky, Olzherassky, Osinnikovsky), the mountain-taiga subzone (Kedrovsky, Chernihiv, Volkov mine). The identification of invasive species was carried out as a result of floristic studies and analysis of more than 200 releves made in 2017-2020. The assessment of naturalization was conducted according to the scale of the degree of naturalization adopted for the adventive flora of the Voronezh Region [6].

There were six gradations of the invasive status: 1) ephemerophyte-epecophyte (EE) - a species that appears on dumps, as a result of periodically occurring drift of diaspores or the extended period of seeds germination of one drift; 2) ephemerophyte-agriophyte (EA) - a species that is periodically appeared on dumps, but does not stay on them for a long time; 3 ) colonophyte-epecophyte (CE) - a species that is more or less firmly fixed on secondary habitats; 4) colonophyte-agriophyte (CA) - a species that grows for a long time on dumps, without spreading in other places; 5) epecophyte (E) - a species that has naturalized in secondary habitats and is spreading further; 6) agriophyte (A) - a species that is firmly introduced into the plant communities on dumps.

\section{Results and Discussion}

26 species of non-native plants were found in the dumps of coal mines (Table).

Table. Invasive status non-native plants on the dumps

\begin{tabular}{|c|c|c|c|c|}
\hline Plants & $\begin{array}{l}\text { The southern } \\
\text { forest-steppe }\end{array}$ & $\begin{array}{l}\text { The northern } \\
\text { forest-steppe }\end{array}$ & $\begin{array}{c}\text { The } \\
\text { mountain- } \\
\text { taiga } \\
\text { subzone }\end{array}$ & Notes \\
\hline Acer negundo L. & EA & EA & EA & $\begin{array}{l}\text { it is noted as a } \\
\text { pioneer of } \\
\text { overgrowth on } \\
\text { the slopes and } \\
\text { tops of sandstone } \\
\text { dumps }\end{array}$ \\
\hline $\begin{array}{c}\text { Amoria hybrida (L.) C. } \\
\text { Presl }\end{array}$ & $\mathrm{CE}$ & $\mathrm{CE}$ & $\mathrm{E}$ & \\
\hline Atriplex sagittata Borkh & EA & EA & $\mathrm{EE}$ & \\
\hline Conium maculatum L. & $\mathrm{EE}$ & & & $\begin{array}{l}\text { it is rare in the } \\
\text { zone of deluvial } \\
\text { flushing of fine- } \\
\text { grained soil from } \\
\text { the dump }\end{array}$ \\
\hline $\begin{array}{c}\text { Conyza canadensis (L.) } \\
\text { Cronquist }\end{array}$ & $\mathrm{CE}$ & $\mathrm{CE}$ & $\mathrm{CE}$ & $\begin{array}{l}\text { on dumps in the } \\
\text { composition of }\end{array}$ \\
\hline
\end{tabular}




\begin{tabular}{|c|c|c|c|c|}
\hline & & & & $\begin{array}{l}\text { pioneer and weed } \\
\text { vegetation }\end{array}$ \\
\hline $\begin{array}{c}\text { Echinochloa crusgalli (L.) } \\
\text { Beauv. }\end{array}$ & EA & EA & EA & $\begin{array}{l}\text { on a highly } \\
\text { weathered } \\
\text { substrate }\end{array}$ \\
\hline $\begin{array}{l}\text { Echinocystis lobata } \\
\text { (Michx.) Torr. et Grey. }\end{array}$ & EA & & & \\
\hline Echium vulgare L. & EE & EA & EA & \\
\hline Elaeagnus angustifolia L. & & $\mathrm{CE}$ & $\mathrm{CE}$ & $\begin{array}{l}\text { on the slopes of } \\
\text { the dumps, the } \\
\text { remains of old } \\
\text { forest stands }\end{array}$ \\
\hline $\begin{array}{c}\text { Epilobium adenocaulon } \\
\text { Hausskn }\end{array}$ & $\mathrm{E}$ & $\mathrm{E}$ & $\mathrm{E}$ & on wet ecotopes \\
\hline Hordeum jubatum L. & & & КЭ & $\begin{array}{l}\text { wet ecotopes, } \\
\text { pockets of fine- } \\
\text { grained soil; not } \\
\text { observed on } \\
\text { dumps until } 2008\end{array}$ \\
\hline $\begin{array}{c}\text { Impatiens glandulifera } \\
\text { Royle }\end{array}$ & & $\mathrm{CE}$ & & $\begin{array}{l}\text { wet ecotopes, } \\
\text { pockets of fine- } \\
\text { grained soil, the } \\
\text { presence of } \\
\text { shrubs }\end{array}$ \\
\hline Lactuca serriola L. & EA & EA & EA & $\begin{array}{l}\text { it is part of the } \\
\text { pioneer } \\
\text { communities }\end{array}$ \\
\hline $\begin{array}{l}\text { Lepidium densiflorum } \\
\text { Schrad. }\end{array}$ & $\mathrm{EE}$ & $\mathrm{EE}$ & $\mathrm{EE}$ & \\
\hline $\begin{array}{l}\text { Lepidotheca suaveolens } \\
\text { (Pursh) Nutt. }\end{array}$ & EE & EA & & on the old dumps \\
\hline Lupinus polyphyllus Lindl. & & & $\mathrm{E}$ & \\
\hline Malus baccata (L.) Borkh. & КЭ & КЭ & КЭ & \\
\hline Medicago sativa L. & $\mathrm{CA}$ & $\mathrm{CA}$ & $\mathrm{CA}$ & \\
\hline $\begin{array}{l}\text { Melilotus officinalis (L.) } \\
\text { Pall. }\end{array}$ & $\bar{E}$ & $\mathrm{E}$ & $\mathrm{E}$ & $\begin{array}{l}\mathrm{n} \text { all types of } \\
\text { dumps, at all } \\
\text { stages of } \\
\text { overgrowth } \\
\end{array}$ \\
\hline Oenothera villosa Thunb. & $\mathrm{CE}$ & $\mathrm{CE}$ & $\mathrm{CA}$ & \\
\hline Pastinaca sativa $\mathrm{L}$. & E & $\mathrm{E}$ & $\mathrm{E}$ & \\
\hline Plantago lanceolata $\mathrm{L}$. & КЭ & КЭ & КЭ & \\
\hline Senecio vulgaris L. & EA & EA & EA & $\begin{array}{l}\text { on old dumps of } \\
\text { loess-like loam }\end{array}$ \\
\hline Solidago canadensis L. & EA & EA & $\mathrm{E}$ & \\
\hline $\begin{array}{c}\text { Tripleurospermum } \\
\text { inodorum (L.) Sch. Bip. }\end{array}$ & $\mathrm{E}$ & $\mathrm{E}$ & E & \\
\hline Ulmus pumila L. & & CA & & \\
\hline
\end{tabular}

At the stage of pioneer groups formation, Lactuca serriola and Pastinaca sativa are found with high constancy in the southern forest - steppe; Melilotus officinalis is found in the northern forest-steppe, and Conyza canadensis is found in the mountain - taiga subzone [7].

An invasive transformer species on the territory of Kuzbass, Acer negundo, actively inhabits dumps at the stage of pioneer groups and group-thicket community, but it manages to firmly establish itself in plant communities only in the mountain-taiga subzone. 
Melilotus officinalis, Amoria hybrida, Epilobium adenocaulon, and Tripleurospermum inodorum are highly active in overgrowing dumps. At the stage of group-thicket communities, these species form single-species communities, and subsequently form mosaic communities with species of natural flora. The most stable are the woody species Elaeagnus angustifolia, Malus baccata, Ulmus pumila these species are more or less firmly fixed on the dumps, but as a rule, they have a reduced vitality.

It should be noted that in comparison with the studies conducted in the 90-s of the XX century, new invasive species began to settle on the dumps, which were not previously observed on the dumps [8].: Hordeum jubatum, Lepidium densiflorum, Lupinus polyphyllus, Solidago canadensis.

\section{Conclusion}

Floristic studies conducted on the dumps of coal mines revealed 26 species of invasive plants included in the Black Book of Flora of Siberia. Invasive species are found at all stages of syngenesis and are of great importance in the formation of the vegetation on dumps. Colonophytes-agriophytes and epecophytes have a high degree of naturalization: Amoria hybrida (mountain taiga subzone), Epilobium adenocaulon, Medicago sativa, Melilotus officinalis, Oenothera villosa (mountain taiga subzone), Pastinaca sativa, Tripleurospermum inodorum, Ulmus pumila (southern forest-steppe).

The work was carried out within the framework of the state assignment of the Federal Research Center of Coal and Coal Chemistry SB RAS (project no. 0286-2021-0010).

\section{References}

1. A.N. Kupriyanov, Yu.A. Manakov, Sib. J. of For. Sci., 51-58 (2016)

2. O.A. Klimova, A.N. Kupriyanov, Sib. J. of For. Sci., 5, 45-53(2018)

3. T.O. Strelnikova, A.N. Kupriyanov, Yu.A. Manakov, Bot. res. Sib. and Kazakh., 21-50 (2009)

4. Mark van Kleunen, Wayne Dawson, Franz Essl at al., Nature, 525, 9,100-107 (2015)

5. The Black Book of the Flora of Siberia (Academ. from "Geo", Novosibirsk, 2016)

6. A.Ya. Grigorievskaya, E.A. Starodubtseva, N.Yu. Khlyzova, V.A. Agafonov, Adventure flora of the Voronezh region: historical, biogeographic, ecological aspects (Voronezh Publishing House. state University, Voronezh, 2004)

7. A.N. Kupriyanov, Yu.V. Morsakova, Sib. Ecol. J. , 2 (2008)

8. Yu.A. Manakov, Bot. res. Sib. and Kazakh, 3, 41-54 (1997) 